\title{
The Impact of Domestic Responsibilities on the Academic Achievement of Married Women in College of Education, Azare
}

\author{
Tata Umar Sa'ad
}

\author{
School of Education, College of Education
}

P. M. B. 044, Azare, Bauchi State, Nigeria

\section{Doi:10.5901/jesr.2014.v4n7p101}

\begin{abstract}
This study focuses on the impact of domestic responsibilities on the academic achievement of married women in College of Education, Azare, Bauchi state. The study sample was one hundred and twenty (120) married women selected through disproportionate stratified random sampling technique. The design adopted for this study was descriptive survey. The instruments for this study were questionnaire and results records. The questionnaire was administered to the sample and end of semester results were collected from the exams offices of the college. It was observed that married women in the College were performing a lot of domestic activities, such as cooking food for the family, taking care of the children, providing sexual satisfaction to their husbands, conception, giving birth, all during their studies period. It was also discovered that married women were finding it difficult in combining academic and domestic activities together but dedication and hardworking were their weapons. Finally, it was found out that they (married women) were also performing well like other students (males and single women) because they obtained a mean of 2.54 CGPA. It was recommended that the service of house help needs to be employed for married women, special scholarship should be provided for married women.
\end{abstract}

\section{Introduction}

The history of western education cannot be separated with the coming of European colonizers into Nigeria. The British missionaries established the first schools in the southern part of the country and later in the north. The primary objective of the early Christian missionaries was to convert "heathen" or the benighted Africans to Christianity via education (Fafunwa, 1995). Against the then growing resentment and dislike for European system of education, particularly in the Muslims dominated areas of northern Nigeria, schools were established, which culminated into the establishment of Nasarawa school in Kano in 1903, among the many early schools set up by the colonial administration. It was well known at that time that those who became early and pioneer pupils were majority from the male population of the northerners.

Like most stereotypes, the fact that women among the northerners were not attracted to such schools in the early days of the coming of western education. This might not be unconnected with the view that women were supposed to be in the "home" as at then. Nigerian women, like women world over and especially in most parts of the developing world, continues to face various forms of discrimination which limit their opportunities to develop to their full potential on the basis of equality with men (UNICEF, 2001).

The fact that women and married ones in particular can be seen in most of our institutions of higher learning has not occurred by chance. It has been the credit of post-modern world, as a result of the cultural changes of human perceptions and ideals. Article ten of CEDAW which contains women's right to education, requires measures to ensure the same opportunities for women in access to programmes of continuing education, including adult and functional literacy programmes, especially those aimed at reducing the gap in education between men and women (UNICEF, 2001).

Education is generally seen as an important factor for human development. Therefore, it is important to give women adequate education for national development. Female education makes it possible to tap the potentials of women to support nation building which seems to be low in sub-Saharan Africa (Forster and Offei-Ansah, 2012). Generally, women are partners in progress even with the domestic responsibilities; they still contribute immensely in almost areas of human endeavour like teaching, medicine, administration, military, police etc. 


\section{Review of Related Literature}

Marriage is normally contracted so that couples will assume a new role in life. Marriage involves mutual obligations. Abdal'ati, (1977) and Lemu, (1990) were of the view that the duties of one married partner are the rights of the other partner. Anyakoha and Eluwa (1999) define domestic responsibilities of married woman as those duties of housekeeping, management and maintenance that when carried out effectively present such woman as a good housewife.

A married woman in African setting undertakes many domestic responsibilities. In fact, married women in Africa mostly combine domestic and academic activities together when schooling. Abdalati, (1977), Lemu, (1990), Maqsood, (2002) and Ali, (2005) were of the view that a married woman is always expected to be obedient to her husband and at the same time provide him with sexual satisfaction. This involves any assignment that might be given to her by the husband. In another vein, married woman is also expected to prepare food for her family and take care of the house in terms of cleaning and taking care of children. Lemu, (1990), Anyakoha and Eluwa, (1999), Potekri, (2011) and Forster and Offei-Ansah, (2012) were of the view that married women in African setting are responsible for preparing and serving food for her family as well as taking care and educating children at home. In many families, married woman engage in many activities which contribute immensely in the continuity and survival of the family. In relation to this UNICEF, (2001) was of the view that by extension, women have always been heavily involved in petty trading, selling their wares in the market and, in the urban setting, hawking in the streets. In addition to that Forster and Offei-Ansah, (2012) found out that some married women worked to raise income for their needs and the needs of their family members when their universities were not on session.

Married women in tertiary institutions mostly never find it easy in combining academic and domestic activities together at the same time. However, many married women became successful academically and even at home. For instance, Professor Rukayyatu Ahmed Rufa'l of Bayero University, Kano obtained all her tertiary education as a married woman. Akinkugbe (1994) and Mercer, (2004) were of the view that married women are finding it difficult in combining school and domestic activities. Sa'ad, (2007) was of the view that combining family roles and schoolwork was very stressful and too demanding among the married women students in tertiary institutions of Bauchi state. Female married students are overwhelmed with work at school and at home and their rate of failure are higher than males because they have less time to study and therefore give their studies less attention (Taniguchi and Kaufman, 2005). The important secret behind the successful achievement of many married women who schooled while married were determination, hardworking, dedication and patience.

Even with the dual responsibilities carried out by married women during their studies, particularly that of tertiary level, some are performing well, others averagely and some poorly. Makosana, (2001) and Mercer, (2004) found out that married women students were having CGPA of 3.00 and above and, in some cases even got scholarship which was based on merit and good grades. In addition to that Sa'ad, (2007) found out that married women in tertiary institutions of Bauchi state also got CGPA of 2.58. This clearly indicated that married women are still coping with combining the academic and domestic activities together during the period of their studies.

Therefore, this study intends to find out the impact of domestic responsibilities on the academic achievement of married women in College of Education, Azare.

\section{Objectives of the Study}

This study intends to achieve the following objectives:

1. Find out the types of domestic responsibilities carried out by married women students in College of Education, Azare.

2. Find out the demands of domestic responsibilities on married women that affect their academic achievement in College of Education, Azare.

3. Find out the level of academic achievement of married women in College of Education, Azare.

\section{Research Design}

The design adopted for this study was descriptive survey. It was used because it permitted the researcher to study small sample and later generalized the findings to the whole population. Osuala (1985) was of the view that in survey research small sample is studied and the findings generalized to the population. 


\section{Research Questions}

This study aims at answering the following research questions:

1. What are the types of domestic responsibilities carried out by married women in College of education, Azare?

2. What are the demands of domestic responsibilities on married women that affect their achievement in College of Education, Azare?

3. What is the level of academic achievement of married women in College of Education, Azare?

\section{Population of the Study}

The population of this study was one thousand two hundred and one married women in College of Education, Azare.

Table 1:Showing the distribution of the population based on school in the College

\begin{tabular}{clc} 
S/No. & Name of School & No. of Married Women \\
\hline 1. & School of Education & 133 \\
2. & School of Arts \& Social Sciences & 448 \\
3. & School of Languages & 385 \\
4. & School of Science & 140 \\
5. & School of Vocational \& Technical Education & 85 \\
& $\quad$ Total & 1,201
\end{tabular}

Source: Fieldwork

\section{Sample for the Study}

The sample for the study was one hundred and twenty (120) married women selected using disproportionate stratified random sampling technique. Osuala, (1985) was of the view that ten percent (10\%) serves as a representative of a population in research.

Table 2:Showing the distribution of the sample based on school in the College

\begin{tabular}{clc} 
S/No. & Name of School & No. of Married Women \\
\hline 1. & School of Education & 13 \\
2. & School of Arts \& Social Sciences & 45 \\
3. & School of Languages & 39 \\
4. & School of Science & 14 \\
5. & School of Vocational \& Technical Education & 9 \\
& $\quad$ Total & 120
\end{tabular}

Source: Fieldwork

\section{Sampling Technique}

Disproportionate stratified random sampling technique was used in this study. This was the kind of sampling technique that allowed the researcher to select a sample that was not only stratified but that the stratification reflects an appropriate to the power of each stratum. Kolo, (1992) was of the view that this sampling technique has the advantage of being sensitive to population variables and capable of differentiating feelings based on population distribution.

\section{Instruments for Data Collection}

A questionnaire and result records were used as instruments of the study. The questionnaire comprises of fourteen (14) items on the impact of domestic responsibilities on the academic achievement of married women in college of education, Azare. On the other hand, the end of semester results of sample were collected from the examination offices of the College of Education, Azare. 
The instrument was validated by experts who have more than two decades of teaching research in college of Education, Azare.

The reliability of the instrument was determined by using test-retest method. The instrument was used on twenty (20) members of the population and after ten days the same instrument was used on the same members. The two results were correlated using Pearson product moment correlation coefficient and the result got was 0.7 . This makes the instrument reliable.

\section{Data Analysis}

The data collected through questionnaire was a discrete one and frequency and simple percentage were used in its analysis while data collected through result records was a continuous one and mean was used in its analysis.

1. Research Question 1: What are types of domestic responsibilities carried out by married women in College of education, Azare?

Table 3:Showing responses obtained from Research Question One

\begin{tabular}{clcccc}
\multirow{2}{*}{ S/NO } & \multicolumn{3}{c}{ Items } & \multicolumn{3}{c}{ Yes } & No \\
& & No. & No. & \multicolumn{2}{c}{$\%$} \\
\hline 1. & Do you normally prepare and serve food for your family during school session? & 97 & 80.83 & 23 & 19.17 \\
2. & Do you keep the house clean when the school session is on? & 93 & 77.5 & 27 & 25.5 \\
3. & Do you conceive and give birth during school session? & 66 & 55 & 54 & 45 \\
4. & Do you take care of children at home or at school during school session? & 62 & 51.66 & 58 & 48.34 \\
5. & Do you supervise and educate children at home when the school session is on? & 61 & 50.83 & 59 & 49.17 \\
6. & Do you normally perform other duties assign to you by your husband during school & 82 & 50.83 & 38 & 49.17
\end{tabular}

Source: Fieldwork

In the above table, $80.83 \%$ of the respondents were responsible for preparing and serving food for their families while schooling but $19.17 \%$ were not. About $77.50 \%$ were responsible for cleaning their homes while $25.50 \%$ were not. $55 \%$ of the respondents were conceiving and giving birth when they were schooling but $45 \%$ were not in addition to that $50.83 \%$ were responsible for supervising and educating their children on both academic and domestic activities. $51.66 \%$ of the respondents were responsible for taking care of children generally even when the school session was on while $48.34 \%$ were not. Finally, 50.83\% were responsible for performing other duties that might be assigning to them by their husbands while $49.17 \%$ were not. Therefore, it is clear that married women in College of Education, Azare engage in a lot of domestic responsibilities while schooling. In other words, they combine academic and domestic responsibilities during studies in College of Education, Azare.

Question 2: What are requirements of domestic responsibilities on married women that affect their achievement in College of Education, Azare?

Table 4: Showing responses obtained from Research Question Two

\begin{tabular}{|c|c|c|c|c|c|}
\hline \multirow[b]{2}{*}{ S/NO } & \multirow[b]{2}{*}{ Items } & \multicolumn{2}{|c|}{ Yes } & \multicolumn{2}{|c|}{ No } \\
\hline & & No. & $\%$ & No. & $\%$ \\
\hline 1. & Do you mostly come to lectures late due to heavy burden of your domestic responsibilities? & 61 & 50.83 & 59 & 49.17 \\
\hline 2. & $\begin{array}{l}\text { Do you have enough time for studies at home due to the fact that you are carrying out other } \\
\text { duties there? }\end{array}$ & 68 & 56.66 & 52 & 43.34 \\
\hline 3. & $\begin{array}{l}\text { Do you have enough time for carrying out individual and group assignment due to the fact } \\
\text { that you are performing other duties at home? }\end{array}$ & 74 & 61.66 & 46 & 38.34 \\
\hline 4. & $\begin{array}{l}\text { Do you normally pay good attention when lecture is going on due to the fact that you are } \\
\text { combining academic and domestic activities during school session? }\end{array}$ & 90 & 75 & 30 & 25 \\
\hline 5. & $\begin{array}{l}\text { Do you mostly rely on your colleagues during test or even examination due to burden of } \\
\text { domestic responsibilities you are performing? }\end{array}$ & 58 & 48.33 & 62 & 51.67 \\
\hline
\end{tabular}

Source: Fieldwork 
In table 4 above, $50.83 \%$ of the respondents mostly come to lectures late due to the burden of domestic activities on them while $49.17 \%$ were not. $56.66 \%$ were having time for studies at home while $43.34 \%$ were not. $61.66 \%$ were having enough time for carrying out individual and group assignment while $38.34 \%$ were not. $75 \%$ were normally paying enough attention when lecture was going on while $25 \%$ were not. Finally, $51.67 \%$ were in no way relying on their colleagues during any test or examinations while $48.33 \%$ were relying on their colleagues. Therefore, it is clear that married women in College of Education, Azare are finding it difficult in combining academic and domestic responsibilities together but they are able to do it successfully with a lot of hard work and dedication. However, they still come to lectures late sometimes.

Question 3: What is the level of academic achievement of married women in College of Education, Azare?

Table 5: Showing responses obtained from Research Question Four

\begin{tabular}{|c|c|c|c|c|c|}
\hline \multirow{2}{*}{ S/NO } & \multirow{2}{*}{ Items } & \multicolumn{2}{|c|}{ Yes } & \multicolumn{2}{|c|}{ No } \\
\hline & & No. & $\%$ & No. & $\%$ \\
\hline 1. & Do you perform in academic activities like the single and male students? & 101 & 94.16 & 19 & 5.84 \\
\hline 2. & $\begin{array}{l}\text { Do you have CGPA of about } 2.40 \text { and above in the current academic session in the } \\
\text { College? }\end{array}$ & 64 & 53.33 & 56 & 46.66 \\
\hline 3. & $\begin{array}{l}\text { Do you expect to win any prize award due to your good academic achievement during } \\
\text { your graduation? }\end{array}$ & 74 & 61.66 & 46 & 38.34 \\
\hline
\end{tabular}

Source: Fieldwork

In table 5 above $94.16 \%$ of the respondents were good in academic activities just like the remaining students (singles and males) while 5.84 were not. $53.33 \%$ were having CGPA of about 2.40 and above in the current academic session. While $46.67 \%$ were not. Finally, $16.67 \%$ were expecting a prize because of their good academic performance while $83.33 \%$ were not.

Based on the exams results of the respondents collected from the five exams offices of the college, the mean CGPA obtained was 2.54. Therefore, it is clear that married women in College of Education, Azare are performing in academic activities just like other students (singles and males) but with a lot of hard work and dedication.

\section{Discussion of Results}

The discussion of findings is presented hereunder according to research questions of the study.

\subsection{Research Question One}

The results of the analysis of research question one showed that the types of domestic responsibilities carried out by married women in College of Education, Azare. These domestic activities include cooking and serving food, cleaning of house, giving birth and taking care of children and so on.

This finding support the assertion of Abdati, (1977); Lemu (1990); Anyakoha and Eluwa, (1999); Maqsood, (2002), Ali, (2005), UNICEF, 2002), Potekri, (2011) and Forster and Offei-Ansah, (2012) who said that married women were responsible for respecting and obeying their husbands, provide sexual satisfaction and bear children, keeping herself and house clean, educating children at home, prepare food and carryout any duty assign to them by their husbands. The findings of this paper also support this view because married women in College of Education, Azare confirmed that by saying that they engage in a lot of domestic activities even when the school session was on.

\subsection{Research Question Two}

The result of the analysis of research question two showed that despite the heavy demands of both academic and domestic activities on married women in College of Education, Azare, they still cope and managed to perform like other students (singles and males). This is mainly due to their hard work, dedication and determination. This seems to agree with the findings of Akinkugbe, (1994), Mercer, (2004), Taniguchi and Kaufman, (2005) and Sa'ad, (2007) who were of the view that married women were finding it difficult in combining school and home activities together, even though some are doing well in both. 


\subsection{Research Question Three}

The findings of this study support the assertion of Makosana, (2001), Mercer, (2004) and Sa'ad, (2007) who said that married women mostly have CGPA of 3.00 and above, and in most cases get scholarship which is awarded based on merit and good grades. In this study too, it was found out that married women in College of Education, Azare were performing better like other students (singles and males) even though they were combining academic and domestic responsibilities together. It also found out that married women in College of Education, Azare have CGPA 2.54.

\section{Conclusion}

Based on the findings of this study, the following conclusions were made;

That married women in College of Education, Azare engage in a lot of domestic responsibilities while schooling. Domestic responsibilities like cooking and serving of food to the family, cleaning of house, taking care and educating children at home, provision of sexual satisfaction to their husbands and performing any duty or assignment that might be given to the by the husbands are types of activities mostly engaged by married women while schooling.

That, the demands or burden of combining both the academic and domestic responsibilities by married women in College of Education was very difficult. However, with a lot of sacrifice, dedication and hardworking, they were able to cope with the dual responsibilities while schooling. However, they still complained of coming lectures late sometimes.

That even with the heavy responsibility of combining domestic and academic responsibilities together, they still performed well by getting or earning a CGPA of 2.58 which is merit and sometimes, some of them were able to even get scholarship given based on merit

\section{Recommendations}

The service of house help needs to be provided for married women by their husbands, particularly during their studies. This will assists a lot in carrying out most of the domestic responsibilities for them, thereby giving the opportunity to direct more time and attention to their studies.

Special scholarship for married women in tertiary level of education needs to be provided either by government, non-governmental organization like UNICEF or private individuals. This will assists them greatly in employing the service of others to help the carry out some domestic activities, particularly where the husband is not able to provide.

Parents should also provide necessary assistance to their married daughters who are pursuing higher qualifications. The assistance can be financially (by giving them money), (physically by taking care of their children), socially (by encouraging them) etc.

Since some married women while schooling conceive and give birth which in most cases affect their academic activities. It is recommended that they should adopt child-spacing, particularly during their studies. This will definitely reduce some burden on them and they can dedicate more time to their studies.

The College should try as much as possible to provide more buses for taking students to and from school because majority of married women are off campus.

The College needs to provide summer semester programme for the students generally. This can allow the married women to clear the courses they failed due to the burden of their dual responsibility.

\section{References}

Abdal'ati, H. (1977). The Family Structure in Islam. Brentwood: American Trust Publications.

Akinkugbe, O. O. (1994). Nigeria and Education: The Challenge Ahead. Ibadan: Spectrum Books Ltd.

Anyakoha, E. \& Eluwa, M. (1999).Home Management for Schools and Colleges. Onitsha:Africana-Feb Publishers.

Ali, Y. (2005). Marriage in Islam. http//cyberbanglaotripod.com/aa/chapterfivehtl. Retrieved24th December, 2007.

Fafunwa, A. B. (1995). History of Education in Nigeria (Rev. Ed). Ibadan: NPS EducationalPublishers Limited.

Forster, P. \& Offei-Ansah, C.(2012). Family Roles and Coping Strategies of Female Studentsin Ghanian Public Universities.International Journal of Academic Research in Businessand Social Sciences 2(5), 191-205. www.hrmars.com/journals. Retrieved on 10th June, 2014.

Kolo, A. I. (1992). Essentials of Research in Education (A Handbook for Beginning Researchers in Education. Ikeja: Text and Leisure Publishers.

Lemu, A. B. (1990). Islamic Studies for Senior Secondary Schools. Minna: Islamic Trust Publication

Makosana, N. Z. (2001). Accessing Higher Education in Apartheid South Africa: A GenderPerspective. Jenda: A Journal of Culture and 
Women Studies. http/l:www.jendajournalcom./vol1,i/makosana. Retrieved on 24th December, 2007.

Maqsood, R. (2002). Path to Happy Muslim Marriage.Lagos: Al-risalah Publication.

Mercer, D. L. (2004). Differences Between Older Women Undergraduates WhenCompared by Marital Status. www.nasadaksu/edu/clearinghouse/Research-Related/purple.pdf. Retrieved on 24th July, 2010.

Osuala, (1985).Introduction to Research Methodology. Onitsha: Africana-Feb Publishers.

Potokri, O. C. (2011). The Academic Performance of Married Women Students in HigherEducation.Unpublished Ph.D Thesis, University of Pretoria, South Africa.oofrontpdf.Retrieved on 12th May, 2014.

Sa'ad, T. U. (2007). Impact of Domestic Responsibilities on the Academic Achievement of Married Women in Tertiary Institutions of Bauchi State. Unpublished M.Ed Thesis.Bayero University, Kano.

Taniguchi, H. \& Kaufman, G. (2005). Degree Comletion Among Non-traditional CollegeStudents. Social Science Quarterly. 86(4), 912927.

UNICEF, (2001).Children's and Women's Right in Nigeria: A Wake up Call: National PlanningCommission and UNICEF. 